\title{
Seasonal Marking in an Otter Population
}

\author{
Sheila M. MACDONALD \& Christopher F. MASON
}

Macdonald S. M. \& Mason Ch. F., 1987. Seasonal marking in an otter population. Acta theriol., 32, 27: 449-462 [With 1 Table \& 5 Figs.]

Observations were made on the marking activity of a population of otters Lutra lutra (Linnaeus, 1758) in Wales, United Kingdom, over the period 1981-1984, with monthly counts of signs at nine $1 \mathrm{~km}$ stretches of river. Marking was found to be distinctly seasonal, with peaks in winter and early spring in all three years of study. During the peak period there were more spraints (faeces), more "jellies" (jelly-like secretions of various colours) and more scratching and rolling. During summer more "smears" (tar-like secretions lacking solid food remains) were found. It is suggested that this seasonal marking pattern may be related to the development or re-inforcement of dominance relationships between otters at a time when young animals become independent of their mothers. Judging by the increasing trend in signs over the study period, this otter population may be increasing.

[Department of Biology, University of Essex, Wivenhoe Park, Colchester C04 3SQ, U.K.].

\section{INTRODUCTION}

The otter Lutra lutra (Linnaeus, 1758) has declined substantially in numbers over much of its European range and is now absent from many areas in which it occurred thirty years ago. Pollution of waterways, especially by organochlorines, and the destruction of bankside vegetation are major factors contributing to this decline (Mason \& Macdonald, 1986).

The naturally low density of otter populations and the secretive, nocturnal behaviour of the animals make their study difficult. Most surveys for otters, upon which conservation measures may be based, involve a search for signs, e.g. faeces, rather than direct observations of animals (see Mason \& Macdonald, 1986). However, our understanding of the significance of different types of sign, or of their use as a system of communication, is limited. This paper describes observations on signs of otters made over a four year period in the catchment of the River Severn, Wales, United Kingdom.

\section{SITE AND METHODS}

The River Severn rises at an altitude of $700 \mathrm{~m}$ on open moorland. The study area $i$ is underlain with hard, base-poor rocks and the water is oligotrophic and very soft. The long-term average flow of the river at stretch 2 (Fig. 1) is 2.5- 
$-5.0 \mathrm{~m}^{3} \mathrm{~s}^{-1}$. In the study area the land use is primarily pasture for sheep and cattle, with some coniferous afforestation.

From 1981 until 1984 the River Severn catchment, upstream of the River Vyrnwy confluence (Fig. 1) was monitored regularly for signs of otters. Between 1982 and $1983,91 \mathrm{~km}$ of the Severn and its tributaries above stretch 5 were walked and searched three times for otter signs and 101 sites were surveyed throughout the upper Severn catchment in 1984-85 by one of us (SMM) as part of the national survey of Wales (Andrews \& Crawford, 1986).

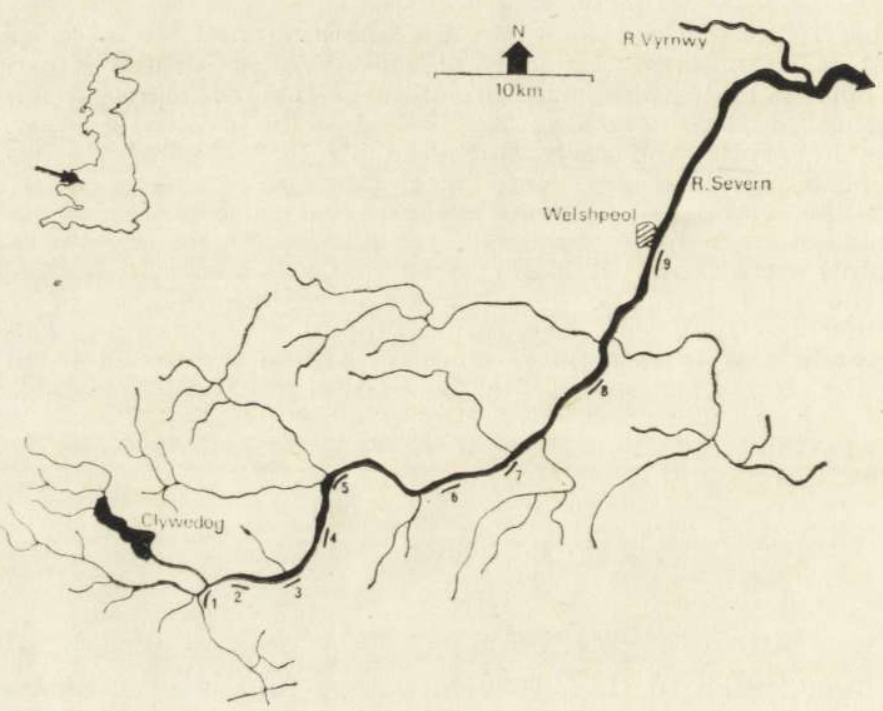

Fig. 1. The catchment of the River Severn, Wales, showing the nine stretches of river monitored for otters monthly $1981-1984$.

Between May 1981 and May 1984, inclusive, nine $1 \mathrm{~km}$ stretches of the main Severn (one bank only) above Welshpool were walked each month (see Fig. 1). Note was made of all sites where signs of otters were found and signs were counted. Signs included spraints (faeces containing food remains), "smears" (tarlike secretions lacking solid food remains) and "jellies" (jelly-like secretions of various colours with the characteristic otter odour). A sprainting site is defined broadly as a site which has been marked with spraints, "smears" or "jelly". In addition, evidence of otters rolling or scratching the substratum was noted, as were "sign heaps" (grass or moss collected into a small mound and frequently marked). Sprainting sites are predominantly traditional places for otters i.e. the same rock or root is marked year after year. However, in the second and third year of this study, special note was made of any sprainting site which had never been marked during the first year.

All otter footprints were measured. Prints measuring less than $45 \mathrm{~mm}$ across 5 toes were considered to be those of young cubs, while tracks larger than this but smaller than $50 \mathrm{~mm}$ may have been those of juvenile animals. Potential holts or resting sites were noted 


\section{RESULTS}

From our various surveys and regular monitoring of the upper Severn catchment it was clear that otters occurred throughout most of the system upstream of the Vyrnwy confluence. However, signs of animals were found only sporadically on the main Severn below Welshpool which, with the lower reaches of the Vyrnwy, is embanked for flood prevention. There is little riparian vegetation and the habitat offers negligible security for otters. Signs were also rare on the top of the Severn where the river flows through conifer plantations and we have never found evidence of animals above the Clywedog Reservoir (Fig. 1).

Our nine $1 \mathrm{~km}$ study stretches fell within the known distribution of

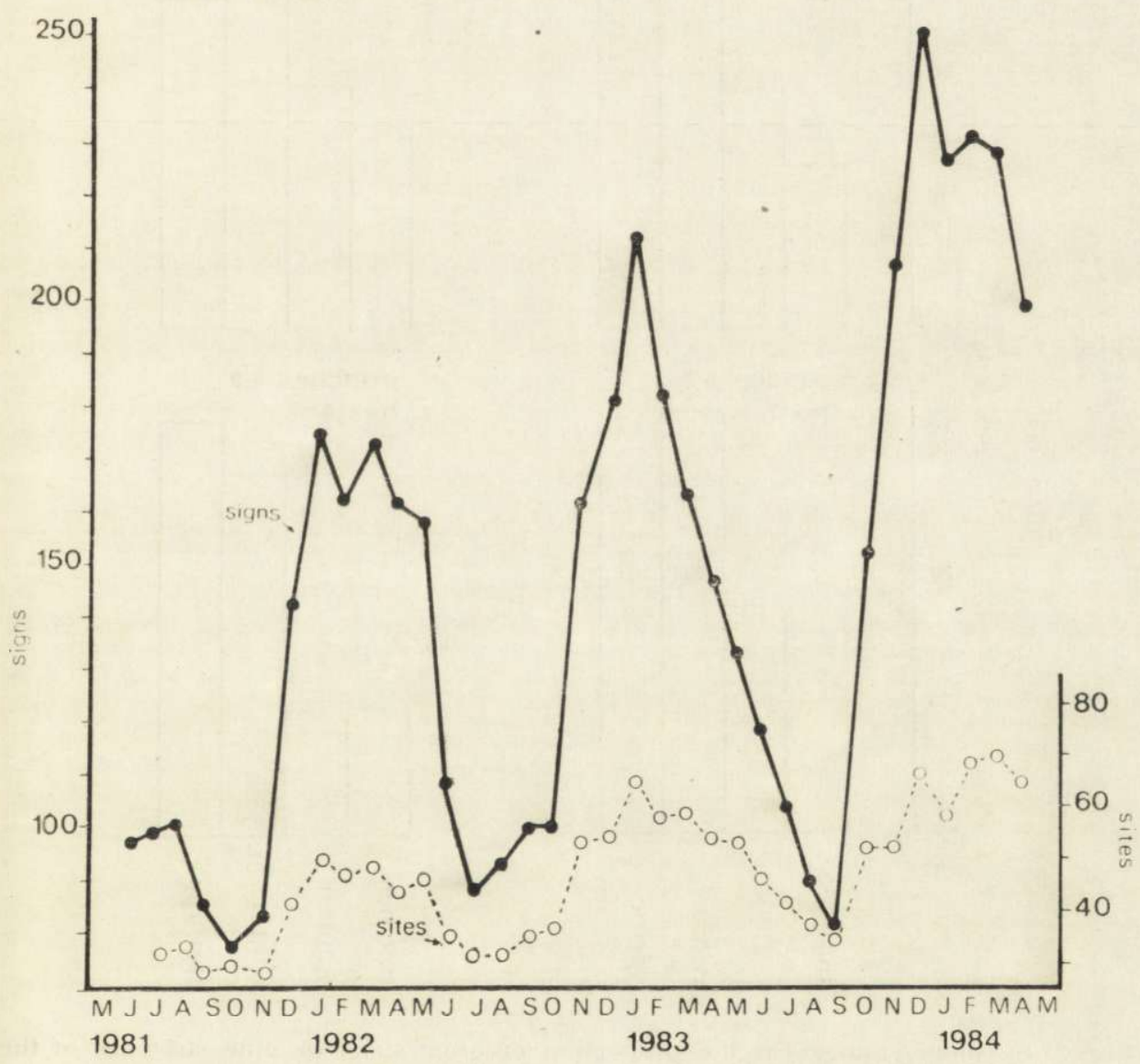

Fig. 2. The total number of otter signs and spraint sites (expressed as 3-point moving averages) recorded along one bank of nine study stretches along the River Severn, May 1981 - May 1984 inclusive. 
resident otters with stretches 1 and 9 close to the upstream and downstream limits respectively (Fig. 1).

There was a seasonal cycle in the total number of signs (spraints and other secretions) of otters and in the number of sprainting sites (Fig. 2), with a clear increase during each winter and early spring. This trend occurred in all sections of the river under study (Fig. 3 , in which survey stretches have been grouped from upstream to downstream). Throughout

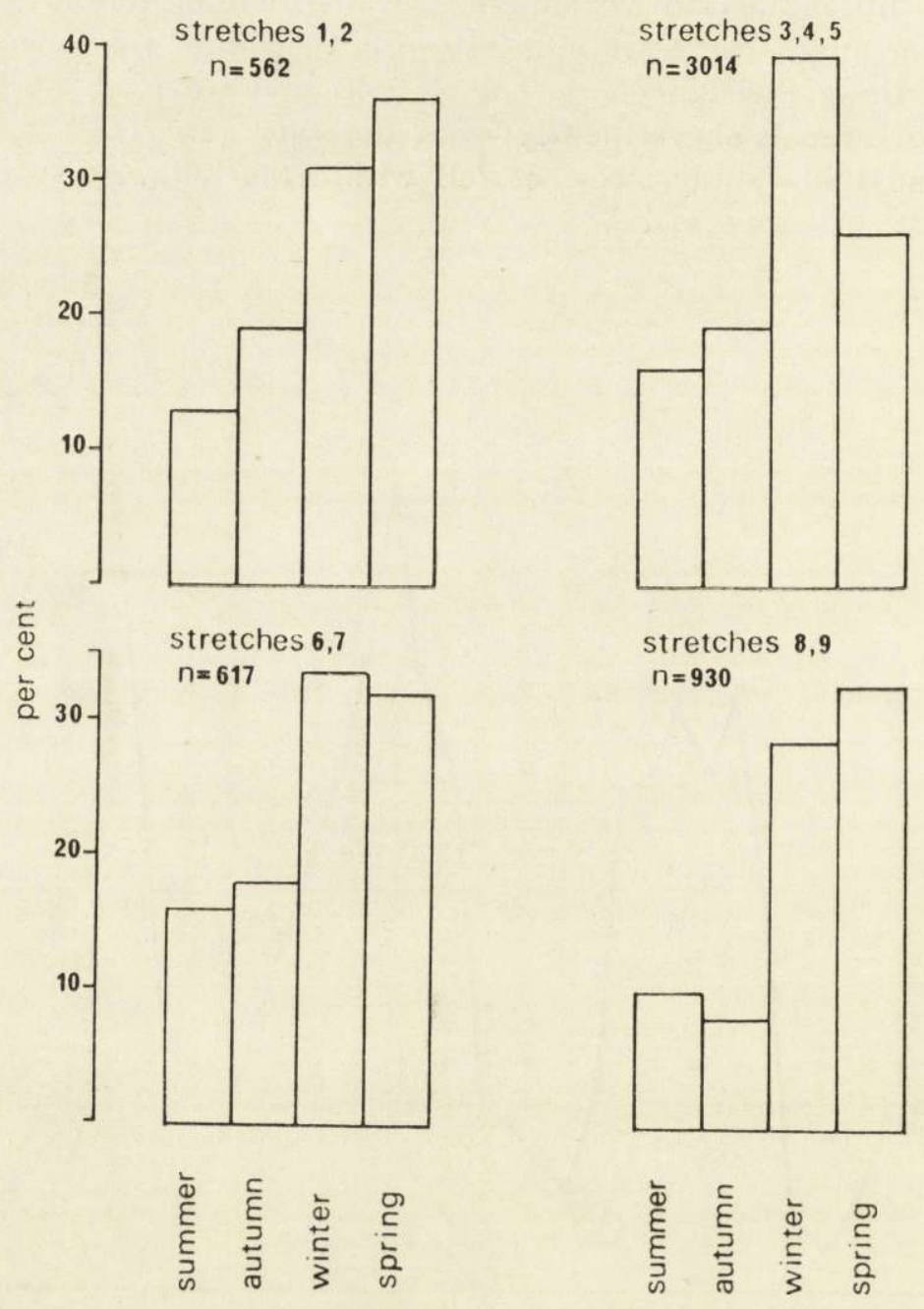

Fig. 3. Seasonal changes in the proportion of otter signs in nine stretches of the River Severn, grouped into four areas from upstream to downstream, data for three years combined (summer includes the months June, July, August; autumn, September, October, November; winter, December, January, February; spring, March, April, May). 
the year the signs most cammonly found were spraints, with lowest numbers being recorded between June and October inclusive. The production of "smears" and "jellies" also varied seasonally. Numbers of "jellies" each month were significantly correlated with spraints $(r=0.79$, $n=12, \quad p<0.01)$, but not with "smears" $(r=0.01, n=12$, n.s. $)$, while "jellies" made up a greater proportion of the total signs in winter and spring (Fig. 4). The number of "smears" recorded each month was not significantly correlated with the number of spraints $(r=0.17, n=12$, n.s.) and most "smears" were found in spring and summer.

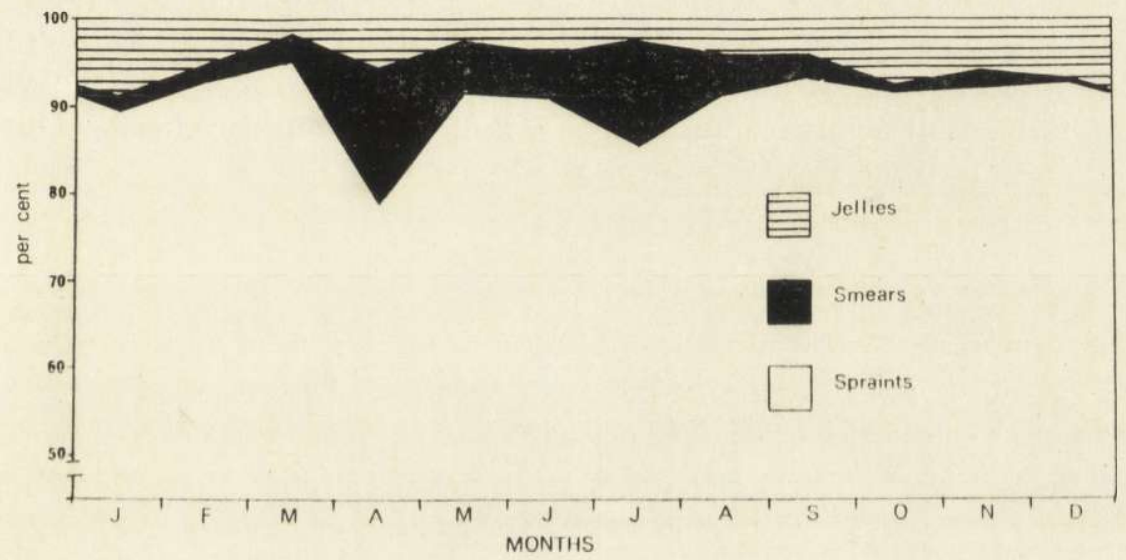

Fig. 4. The proportion of spraints, "smears" and "jellies" recorded each month, May 1981 - April 1984 inclusive, along nine stretches of the River Severn.

Additionally, scratching of the substrate was recorded 55 times, 53 of these being between November and January (Table 1). Rolling, resulting in extensive flattening of the grass on the bank, was recorded 34 times, $79 \%$ of these in the period November to January. Sign heaps were found on only 9 occasions, 7 of them between November and January. During the winters the otters also created "signal sites" comprising areas of grass around $1 \times 2 \mathrm{~m}$ in size which were scratched and smeared with

Table 1

The number of times scratching, rolling, sign heaps and new sprainting sites were recorded for each month.

\begin{tabular}{lrlllllllllrr}
\hline Month & J & F & M & A & M & J & J & A & S & O & N & D \\
\hline Scratching & 13 & 3 & 4 & 4 & 5 & 2 & 2 & & 2 & 4 & 9 & 7 \\
Rolling & 6 & & & & & & 1 & & & 6 & 11 & 10 \\
Sign heaps & 1 & & & & & & 1 & & 2 & & 3 & 3 \\
New sites & 7 & 9 & 5 & 4 & 3 & 2 & 1 & & 1 & 2 & 12 & 5 \\
\hline
\end{tabular}


spraints and "jelly". Eleven such sites were found on the study stretches, all were intensively marked between November and February but from March the grass began to recover and only occasional spraints were found at these sites during the rest of the year. The same locations were used during the winters of all three years of study. All 11 sites were located on banks devoid of woody vegetation and 9 of them were on banks elevated at least $1 \mathrm{~m}$ above normal water levels. Judging from track sizes in snow, "signal sites" were visited by more than one animal,

The otters usually marked the same specific sprainting sites. As examples, on one stretch, despite varying weather conditions, two hollows low in the bank were each found to be marked on 29 of 36 monthly checks, the root of an oak was found to be marked on 25 of the visits and a fallen willow was marked on 24 of the monthly checks. Out of

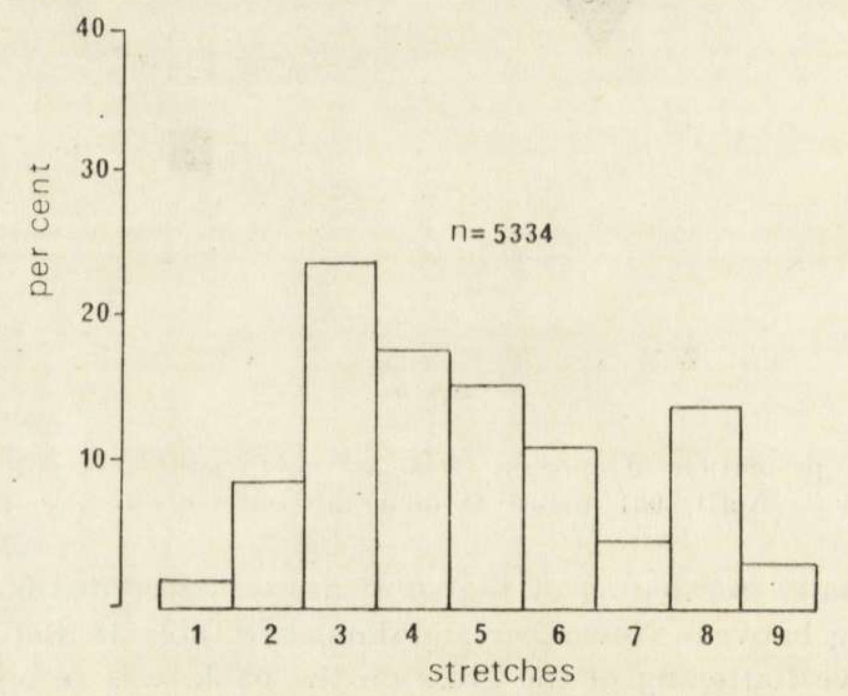

Fig. 5. The proportion of the total signs of otters recorded in each of nine stretches of the River Severn, May 1981 - May 1984 inclusive.

the 36 monthly visits there were only 3 occasions when none of these 4 sites was marked and these coincided with severe and prolonged spates. Despite this conservatism, spraints were sometimes found at new nontraditional sites. This occurred 51 times, $65 \%$ being between November and February. The increases in the number of sprainting sites found in the winter and early spring (Fig. 2) are due both to the marking of more of the traditional sites and to the use of new sites. Twenty-six new sites were found in the second year of the work and 25 in the third.

The numbers of signs and of sprainting sites found in the winter and early spring increased over successive years (Fig. 2).

Judging from track sizes, young cubs were recorded 9 times; once 
in each of February, April, June and August, twice in May and three times in January. Thus, the majority of small cubs were found in winter and spring and none were detected from September to December, inclusive. Four of the 9 records derived from one upstream stretch of the river (stretch 3) which contained the highest number of potential holts or resting sites and the confluence of a small stream (well used by otters) which led to a secluded lake. This stretch produced the highest percentage of the total number of signs recorded from all 9 stretches over the three years (Fig. 5). Three records of cubs derived from stretch 8 and one each from 4 and 5 . Fewest signs were found on stretches 1 and 9 and these are close to the upstream and downstream limits of the resident otter population at the time of study.

\section{DISCUSSION}

Otters on the Severn are largely confined to the upper reaches in Wales. From our regular monitoring and intensive searches for other signs between 1981 and 1984, we concluded that animals were resident on the main river upstream of Welshpool. They are also resident on much of the Vyrnwy (Fig. 1) but signs were only found occasionally on the embanked lowest reaches of the Vyrnwy or on the Severn below Welshpool. This part of the catchment is largely devoid of riparian vegetation, being heavily managed for flood prevention. Since, on many Welsh rivers, otters seem to require bankside cover and the root systems of mature riparian trees as resting sites (Macdonald \& Mason, 1983), it is possible that a lack of cover restricted the otters' use of the embanked section of the river (see Mason \& Macdonald, 1986, p. 112). However, since otter signs were sometimes found below Welshpool, animals did visit the area. Signs were recorded in February 1982, 1983 and 1984 several kilometres below Welshpool and in February 1984 they were also found some $35 \mathrm{~km}$ downstream of Welshpool on the main river. If the population in the upper Severn is expanding, dispersal into lower sections is to be expected. Dispersal into the headwaters is hampered by a lack of food as the waters are acidified (Mason \& Macdonald, 1987).

The number of otter signs found in winter and spring (November to April inclusive) increased in successive years (54\% between the first and third years of study). Increases occurred on 7 of the 9 stretches, only stretches 7 and 9 showing a decline. The riparian vegetation and a known holt were destroyed during the study period at stretch 9 , but no obvious changes occurred at stretch 7 . It is notable that the stretches found to be the most heavily marked by otters at the start of the study (stretches $2,3,4$ and 8), situated in the best habitat and thought to be centres of 
otter activity, showed the smallest increases in numbers of signs over the years $(8-65 \%)$. The greatest proportional increases in signs occurred in less suitable habitat at stretch $1(595 \%)$ which was close to the upper limit of the known distribution of otters, stretch 5 (265\%), a stretch of largely bare bank containing two river confluences, and stretch $6(251 \%)$ within the boundaries of a town.

In the report of the national field survey of Wales (1984-85), Andrews and Crawford (1986) suggest that the distribution of otters on the Severn has recently increased since $27 \%$ more sites were found to be positive in 1984-85 than in the first survey of Wales in 1977-78. There are problems with any attempt to replicate field surveys, e.g. variation in the competence of surveyors, weather conditions etc. (see Mason \& Macdonald, 1986) but Andrews and Crawford are confident that there have been real increases in much of mid-Wales including the Wye catchment $(+38 \%)$. The headwaters of Wye and Severn tributaries are in close proximity and otters could easily pass between catchments. It may be of interest that during January and February 1981-1984 we counted all otter signs on a $1 \mathrm{~km}$ stretch of the Wye at Builth Wells. The number of signs increased by $236 \%$ over the four years. This apparent increase may be due to restrictions in the use of organochlorine pesticides, while the banning of otter hunting in January 1978 may also be significant.

It is clear from Fig. 2 that there was a seasonal cycle in the number of signs found on the Severn, with marked increases in the winter and early spring. It could be suggested that cycling in a riverine habitat simply reflects seasonal changes in the ease of finding signs. On lowland rivers, for example, dense summer herbaceous growth can pose problems. However, in our study area, the most difficult period for surveying was the winter and spring when spates, due to rain and snow-melt, were frequent. It might then seem that the increase in marking levels at this time reflected a response by the otters to the washing away of their signs. This idea cannot be totally dismissed but the type of sign also varied seasonally. Spraints were, at all times, the commonest sign to be found with highest numbers occurring in winter and spring. "Jellies" were most often seen in the winter and evidence of rolling, scratching and the production of sign heaps were mostly found between November and January. Non-traditional sprainting sites were recorded chiefly between November and February while "signal sites" were consistently and heavily marked in November to February but largely deserted during March and for the rest of the year. Fig. 2 then shows that overall, most signs were found in winter/spring but that certain types of sign were produced predominantly in winter only. By contrast, "smears" were most often noted in spring and summer. 
Erlinge (1968), working in Sweden, found most sprainting activity during October to March with few spraints deposited in June and July. Conroy \& French (in press) found a winter/spring peak in spraint numbers on Shetland coasts. None of these authors, however, distinguish between types of deposit and our results suggest that the type of sign may have some significance. Erlinge (1967) did describe rolling places which may correspond to our "signal sites". In Sweden these were most frequently found in autumn and winter but they were usually hidden under bushes while, on the Severn, all were on tree-less grass banks. By contrast, Jenkins \& Burrows (1980), working on a loch/river system in N.E. Scotland, found no consistent seasonal marking pattern and concluded that peaks in sprainting activity could be attributed to the presence of young animals.

Given that a clear seasonal marking pattern emerged on the Severn, possible reasons for this could be considered. Firstly, the increase in signs could be due to the emergence of cubs or, secondly, it could be related to the time when most young become independent and resident animals need to reinforce any dominance relationships within the local population. Thirdly, the defence of resources may become important at times when food supplies become limiting.

Most of the evidence of young cubs on the Severn was found in the winter and spring but with a seasonal range of January to August. The sample size (9) is, however, very small. On a tributary of the neighbouring Wye we recorded small cub tracks 5 times, once each in March, June and August and twice in May. Again the sample is small but again, despite frequent searches, no small tracks were recorded in the autumn. It must be emphasized that the finding of prints is dependent on the availability of sand, mud or snow and it is very likely that the presence of young animals was not always detected.

Erlinge (1967) found that most Swedish otters were born in the spring and in the USSR breeding is said to be confined to spring and summer (Danilov \& Tumanov, 1975). According to Kruuk et al. (in press), 85\% of all litters on Shetland are born between May and August. This suggests a more precise seasonality in breeding behaviour than is apparent from the cub records on the Severn. It may be that, on the Severn, a high proportion of otters are born from early winter through spring and Green et al. (1984) thought that, on their study river in central Scotland, most births occurred in winter and spring.

In our study, some local fluctuations in numbers of signs may have been related to the presence of cubs. On one stretch, for example, negligible marking in March was followed by a sharp increase in April when the tracks and play area of a very small cub(s) were found. Although 
4 litters were recorded in January or February when overall numbers of signs were high, a further 5 litters were recorded at times when the overall number of signs was declining. Given our limited data it may be unwise to speculate too far but the evidence suggests that seasonality in sign numbers is not related to the emergence of cubs.

If, however, most otters on the Severn are born in early winter to spring and if they remain with the mother for up to one year (see Erlinge, 1967), then it may be that most dispersal by young animals will take place in winter and spring. Resident animals may need to reinforce their dominance relationships. Green et al. (1984) from results of radio-tracking, thought that dominant males maintained exclusive territories while young males were relegated to sub-optimal habitats and had smaller ranges. Jenkins (1980) found that one young male travelled $68 \mathrm{~km}$ after leaving its mother.

As already mentioned, many types of sign increased in the winter months. Unfortunately, however, without the aid of radio-tracking, we have no way of understanding the significance of signs such as "signal sites". Eleven of these sites were found and all were on treeless banks, most being on elevated banks, which may have increased their value as scenting posts. It was not otherwise obvious why these particular spots were chosen each year. They were not, for example, all close to prominent features such as stream entrances. The significance of "jelly" deposition is not clear either. Gorman et al. (1978) thought that both sexes produced jelly from anal glands and related production to the female sexual cycle but Trowbridge (1983) considered "anal jelly" simply to be gut mucus. Certainly otters do pass gut mucus but the jellies found on the Severn varied in both colour (black, green, yellow or white) and in texture. That their deposition was largely seasonal (Fig. 4) suggests that they have some social significance.

The increase in marking in the winter especially, but also in the spring, may indicate that dominance hierarchies are established, for the most part, at this time. Resident animals may defend their ranges more vigorously in periods when young otters are dispersing. Erlinge (1968) related high levels of sprainting in October to March to the time when young males were setting up their territories. Our own records of animals downstream of the usual otter range on the Severn were made in Februaries of each year and we have similar evidence of winter downstream movements on a tributary of the Wye (pers. obs.).

If, as Kruuk et al. (in press) claim, most coastal otters in Shetland are born between May and August, with a gestation period of some $61-74$ days (Wayre, 1979), it might be expected that most mating and dispersal in Shetland would occur around February to May. It may be significant 
that numbers of signs on the Severn started to increase earlier in the winter than on Shetland (Conroy \& French, in press).

While the numbers of several types of sign increased in the winter, most "smears". were found in the spring and summer with a sudden peak in April. It may be that in summer, when females are with young, there is less need for males to defend their ranges. Not only is the summer level of marking low but the type of signal is more discrete!

Kruuk et al. (in press) relate breeding seasonality to changes in food availability in the coastal waters of Shetland. In our study area, the principal fish species present are salmonids (mainly trout Salmo trutta and salmon S. salar), eels (Anguilla anguilla), and coarse fish (principally dace Leuciscus leuciscus and chub Leuciscus cephalus). Fourteen species bf fish have been recorded in the 9 study stretches, but both overall numbers and species richness decrease progressively upstream (Dr. E. North, in list.). The diet of otters has not been determined on the River Severn, but all of these fish species, together with small numbers of amphibians, birds and mammals feature in the diet in other parts of Britain (see review in Mason \& Macdonald, 1986). In the winter period the river generally flows more deeply, more swiftly and is more turbid, which may make feeding more difficult for otters. Eels appear not to feed during the cold winter months (Sinha \& Jones, 1975) and they tend to hide in mud, under rocks and amongst tree roots, so that otters may have difficulty in capturing them, relying more on touch than sight. Eels form a smaller proportion in the diet of otters in winter in south west England (Wise et al., 1981). Eels are also in poorer condition in winter (S. Gentry, unpublished data). Conversely, trout spawn from October to January and salmon in November to Janury, so that salmonids are probably more readily available to otters in winter and in better condition. Coarse fish are available at all times of year. They tend to shoal in deeper, quieter water during winter and are less active at lower temperatures, probably making them more easily caught by otters. More detailed work is obviously required on the food resources of otters, but we think it unlikely that the great increase in marking behaviour in winter and early spring is caused by the defence of a declining food resource.

We suggest that the increase in marking in winter and spring is related to the development or reinforcement of dominance relationships between animals at a time when young animals are becoming independent of their mothers and seeking to establish home ranges. 


\section{REFERENCES}

1. Andrews E. L. \& Crawford A. K., 1986: Otter survey of Wales 1984-85. Vincent Wildlife Trust, London.

2. Conroy J. W. H. \& French D. D., (in press): The use of spraints to monitor populations of otters (Lutra lutra L.). Symp. Zool. Soc., Lond.

3. Danilov P. I. \& Tumanov I. L., 1975: The reproductive cycles of some mustelid species. Biul. Mosk. Obšč. Ispyt. Prir., Otd. Biol. 80: 35-47.

4. Erlinge S., 1967: Home range of the otter Lutra lutra L. in southern Sweden. Oikos, 18: 186-209.

5. Erlinge S., 1968: Territoriality of the otter Lutra lutra L. Oikos, 19: 81-98.

6. Gorman M. L., Jenkins D. \& Harper R. J., 1978: The anal scent sacs of the otter (Lutra lutra). J. Zool., Lond., 186: 463-474.

7. Green J., Green R. \& Jefferies D. J., 1984: A radiotracking survey of otters Lutra lutra on a Perthshire river system. Lutra, 27: 85-145.

8. Jenkins D., 1980: Ecology of otters in northern Scotland. 1. Otter (Lutra lutra) breeding and dispersion in mid- Deeside, Aberdeenshire in 1974-79. J. Anim. Ecol., 49: 713-735.

9. Jenkins D. \& Burrows G. O., 1980: Ecology of otters in northern Scotland. III. The use of faeces as indicators of otter (Lutra lutra) density and distribution. J. Anim. Ecol., 49: 755-774.

10. Kruuk H., Conroy J. W. H. \& Moorhouse A., (in press): Seasonal reproduction, mortality and food of otters Lutra lutra L. in Shetland. Symp. Zool. Soc. Lond.

11. Macdonald S. M. \& Mason C. F., 1983: Some factors influencing the distribution of otters (Lutra lutra). Mammal Rev., 13: 1-10.

12. Mason C. F. \& Macdonald S. M., 1986: Otters: ecology and conservation. Cambridge University Press, Cambridge.

13. Mason C. F. \& Macdonald S. M., 1987: Acidification and otter (Lutra lutra) distribution on a British river. Mammalia 51: 81-87.

14. Sinha V. R. P. \& Jones J. W., 1975: The European freshwater eel. Liverpool University Press, Liverpool.

15. Trowbridge B. J., 1983: Olfactory communication in the European otter (Lutra l. lutra). Ph.D. thesis, University of Aberdeen.

16. Wayre P., 1979: The private life of the otter. Batsford, London.

17. Wise M. H., Linn I. J. \& Kennedy C. R., 1981: A comparison of the feeding biology of mink Mustela vison and otter Lutra lutra. J. Zool., Lond., 195: $181-213$.

Received February 6 1987, Accepted April 101987.

\section{Sheila M. MACDONALD i Christopher F. MASON}

\section{SEZONOWOSC ZNAKOWANIA TERYTORIALNEGO W POPULACJI WYDRY}

\section{Streszczenie}

Obserwowano intensywność znakowania terytoriów w populacji wydry Lutra lutra (Linnaeus, 1758) w Walii (Wielka Brytania) w latach 1981-84. Co miesiąc kontrolowano 9 jednokilometrowych odcinków rzeki (Ryc. 1). Znakowanie bylo 
wyraźnie sezonowe $\mathrm{z}$ największym nasileniem zimą i wczesną wiosną we wszystkich trzech latach badań. W tych porach roku liczba porcji kału, śluzowych wydzielin różnej barwy oraz śladów drapania i tarzania się była większa, niż w pozostałych okresach (Ryc. 2 i 3). Latem natomiast znajdowano więcej śladów gęstej czarnej wydzieliny bez resztek stałego pokarmu (Ryc. 4 i 5). W pracy sugerowane jest, że sezonowa dynamika znakowania może być związana $\mathrm{z}$ ustalaniem się struktury dominacyjnej między wydrami w czasie, gdy młode osobniki stają się niezależne. W ciągu trzech lat badań zaznaczył się wzrost liczby wszystkich rodzajów znakowania, co może świadczyć o wzroście liczebności wydry na tym terenie (Tabela 1). 